Samuel A. Lillo

\title{
La tembladera
}

\author{
Del libro *Bajo la Cruz del Surs. \\ que aparece en eslos dias.
}

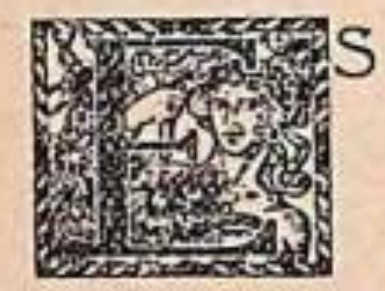

el potro forastero que en la última invernada con la rústica manada de las hembras se juntó.

Nadie sabe cómo vino

este inquieto peregrino

a las tierras del copihue y del piñón.

Hay arranques de gacela

en los nervios de sus piernas cuando vuela con sus hembras de los montes al través;

y si un perro o algún hombre se avecina al lugar de su reposo, sacudiendo la cabeza noble y fina

se adelanta con fiereza

de rey moro que pelea por su harem.

Cuando un día los aldeanos,

- con esfuerzos sobrehumanos. 
consiguieron apartar

de su jefe la manada

y encerrarla tras la fuerte empalizada

del corral,

quedó el potro inquieto $\mathrm{y}$ fiero

sobre el puente que atraviesa

los pantanos del estero.

Con el pecho y la cabeża,

golpeó

vanamente los tablones

de la puerta que el camino le cerró.

Corrió luego río arriba

por la orilla del cercado

contemplando con dolor

en la vega al otro lado,

a la viva claridad de la mañana,

a sus hembras esperando la inhumana

granizada del rebenque trillador;

entretanto los costeños campesinos, en la era,

sin dar tregua a las latigas.

al compás de alegre coro

soñador,

recogian con los bieldos las espigas

levantando un monte de oro

que brillaba de esperanzas bajo el sol.

No encontrando puerta o vado,

el cuitado

vuelve atrás 
y desciende hacia la playa,

al paraje donde entra libremente

la corriente

del riachuelo al litoral.

Alli está la tembladera, honda sima traicionera que otro tiempo cubrió el mar, y que hoy llena

viva arena

movediza,

por encima de la cual

se desliza

dulcemente

el estero, que parece un inocente manantial.

Avisado por su instinto, temeroso y desconfiado, en la orilla se paró

$y$, al sentir el suelo blando

de la esquiva tembladera,

volvió grupas resoplando

y, con rápida carrera,

de la linfa engañadora se alejó.

El relincho de una inquieta compañera

lo contuvo vacilante;

luego, dócil a la voz reclamadora, galopando se volvió, 
y, anhelante,

desde el margen de la grieta acechadora,

la manada de sus hembras contempló.

Con la crin ondeante al viento, sudoriento

se detuvo recordando los enormes,

raudos saltos que antes diera en el boscal,

cuando iba persiguiendo las potrancas

por quebradas y barrancas

impelido por su ardor primaveral.

Con el cuerpo estremecido de un pavor desconocido, en las aguas silenciosas olfateó;

mas, de súbito, rompiendo las cadenas de sus miedos, en las húmedas arenas.

se afirmó,

$y$, elevándose en las manos un instante,

con el cuello distendido,

semejante

a un felino gigantesco, sobre el cauce se lanzó.

Con la fuerza de su anhelo

y su empuje colosal,

tocó el borde del riachuelo

con sus cascos, un segundo

su cabeza se irguió fuera

del raudal; 


\section{La tembladera}

pero el monstruo de la arena que dormía

en sus grutas misteriosas

como enorme calamar.

lo hundió, envuelto entre la fría

red de ávidas ventosas,

bajo el pálido cristal.

$Y$ al sumirse en la profunda

hendidura inesperada

su cabeza señorial,

un relincho de la bestia moribunda

cual la última llamada

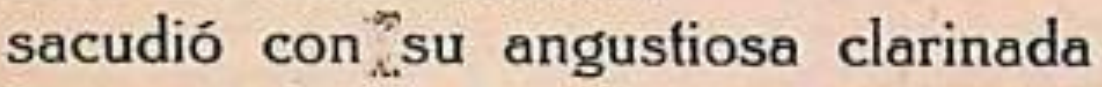

la quietud del arenal.

Al oirlo, las gaviotas espantadas

del estero se alejaron

rumbo al mar.

y las hembras encerradas

se agitaron

relinchando en el corral.

De repente,

una de ellas, con sus cascos delanteros

apoyados en la cerca de tranqueros. levantando la cabeża por encima del tropel, dió a los vientos un gemido dolorido

como un llanto de mujer. 
Ya está el sol con su luz plena;

la faena

va a empezar;

por los látigos golpeadas

van las hembras resignadas

en la era

a galopar;

en aligeras bandadas,

otra vez en la ribera,

juguetean las gaviotas, y hacia el mar,

como siempre, mansamente

se desliza por la arena el trasparente manantial. 